\title{
An Open Letter to the President
}

\section{The Future of the Consultant in Psychiatry: A Continuing Debate}

\author{
P. D. RoHDE, Consultant Psychiatrist, St Mary Abbots Hospital, Kensington, London
}

The President issued a note for discussion by Council on the 'Future Role of the Consultant in Psychiatry' in November 1982. The fourth point of the note concerned the relationship to non-medical disciplines:

The multidisciplinary team approach is fashionable in psychiatric practice. College policy is set out in the report, 'The Responsibilities of the Consultant in Psychiatry within the NHS,' endorsed by Council in 1977 (Bulletin, September 1977, pp 4-7)-'The legal, professional, ethical, diagnostic and prescriptive responsibilities of the medical profession cannot be delegated to a multidisciplinary group when treating an individual patient. Each doctor (consultant) must formulate his own opinion, whether assisted in this process by others or not. Multidisciplinary in this context, from the medical point of view, is a process of consultation, the final decision resting with the consultant where the consultant has the final responsibility.

The Parliamentary debate of the Mental Health (Amendment) Bil has revealed a strong tide of opinion flowing against the above position. Should Council reappraise its stance or are we happy to rest on the statement promulgated five years ago?

My reply to the President's request for comment is now published with his permission.

\section{Dear Professor Rawnsley}

I write in response to your request for comments on the future role of the consultant, specifically on your paragraph 4-'Relationship to non-medical disciplines.' I feel there is a need for a clear College statement to help all psychiatric consultants understand their legal authority and responsibility and to define their roles in relation to the now fashionable multidisciplinary teams.

Rereading the College's 1977 statement,' I find that it has worn well and it is particularly useful to be reminded of the Godber definition and the provisions of the National Health Service and other Acts in relation to consultant responsibility. The actual 14 responsibilities listed in the latter part of the document I find more satisfactory than the brief quote in your paragraph. In particular, paragraph 6, stating that authority may be delegated, is probably more realistic than your extract saying that it cannot be delegated to a multidisciplinary group. In practice, I believe this responsibility is delegated quite widely and the more useful point is to emphasize paragraph 7 of the document where it clearly states that the consultant is the leader of the multidisciplinary team when dealing with clinical problems.

To some extent the 1977 statement is out of date. Discussion in relation to the Nodder Report and the Mental Health Act has, as you yourself have pointed out, revealed a strong tide in favour of the multidisciplinary team to an extent not visualized in 1977, and I know that all over the country, discussion, more or less acrimonious, goes on as to the powers, constitution and leadership of the multidisciplinary team in psychiatry. In a recent series of clinical seminars in my hospital, at which each discipline was asked to discuss its role in community psychiatry, all professions were asking for more involvement in decision taking, and to some extent, in leadership. All this can be seen as a steady political shift from the all-pervading power of the medical superintendent to a possible future where all professions have equal status in the team. If this shift continues unchecked, where should it end? Should doctors in general, and psychiatrists in particular, make a stand and maintain that their unique responsibilities continue to make them the leaders of the team?

The Nodder Report ${ }^{2}$ confuses rather than clarifies this. Tony Smythe, the then Director of MIND and a member of the Nodder Working Group, said at the MIND 1980 National Conference that 'the Working Party never solved the problem of the doctors.' I agree with him in that the final document refers in different places to the special responsibilities of the consultant, i.e. para 6.15, yet gives no clear answers on the question of leadership in the multidisciplinary team. The new Mental Health Act, on the other hand, in spite of all the discussion to the contrary, actually appears to strengthen the consultant's claim to be responsible for the overall treatment plan, since for detained patients at any rate, even non-physical treatments and the overall treatment regime are made explicitly the responsibility of the responsible medical officer. Earlier, the Trethowan Report ${ }^{3}$ made an explicit reference to the fact that: '...clinical psychologists in the National Health Service should be recognized as having full professional status. However, we fully recognize that for any patient under treatment of the National Health Service, there is a continuing medical responsibility which cannot be handed over to any other profession...' (para $6 \mathrm{ff}$., summary and recommendations).

The most useful and careful statement of the consultant role comes from the Report of the Committee of Inquiry into Normansfield Hospital, 4 a painstaking independent report, made all the more useful because it was an analysis of what can go wrong and which cannot in any way be considered a whitewash of the consultants' role since the Committee recommended that the individual concerned should have his appointment terminated and he should not be re-employed in the Health Service. The Committee pointed out that multidisciplinary management teams operated at three levels. The first concerns the management of the Service as a whole, the second the management of therapeutic resources and the third, management of the individual patient. At the first two levels, the consultant operated on an equal basis with the 
other members of the team, but at the third level, 'the Consultant enjoys primacy and authority at the price of medical and legal responsibility'. The Committee go on to quote with approval, paragraphs 6 and 7 of the College's document, saying that they see no conflict between their view and the Royal College's view (see Report of the Committee of Inquiry into Normansfield Hospital, Section V, paras 235-45, p 118-20).

This statement in the Normansfield Report with the emphasis on planning being by multidisciplinary teams as equals and clinical management by multidisciplinary teams with the consultant as leader would appear to combine the College's statement and points of view, such as that of the Nodder Committee. I therefore think that any new College statement should take into account the Normansfield Inquiry.

There remain the problems of the consultant's responsibility outside National Health Service territory. Here I feel the College would do well to adopt a geographical concept of responsibility in the multidisciplinary team. It is clear that a consultant relating to a multidisciplinary team in a Day Centre or Part III accommodation, where the care and resources are being provided by the Local Authority and not by the National Health Service, cannot expect to be more than a partner when discussing management with the team who are actually providing the care. In such a setting the responsibility would appear to be with the director or matron of the institution with the chain of responsibility going up to the Director of Social Services.

Between what is clearly Local Authority territory and National Health Service premises is the community, and inevitably I feel there would be a grey area of responsibility where different professionals are involved with the same patient. If hospital-based staff extend out into the community as members of a consultant team and by consultant request, they may continue to be responsible to the hospital consultant. When a community psychiatric nurse is working with a general practitioner, the medical responsibility will remain with the general practitioner. But there may be cases when a Local Authority social worker, general practitioner and consultant psychiatrist may all be involved and seeing the patient in the community. In such cases there may be no clear leader and the responsibility may be shared. It is in just these cases that a Code of Interprofessional Ethics should exist (or be rediscovered). Any professional on being consulted, should, in turn, be obliged to consult others already involved before getting involved. As with etiquette between doctors, the newly involved should defer to those already having the responsibility for care where there may be conflict.

I recommend therefore that the College:

(i) Issues a revised statement continuing to reaffirm the consultant's role as leader of the clinical team in the hospital, but taking into account the continued movement into multidisciplinary teams and community psychiatry, and considering that in some settings (planning and outside the NHS) the consultant may not be the automatic leader.

(ii) The College should take the initiative in contacting other professional bodies for an interdisciplinary statement on ethics in community psychiatry.

Yours sincerely

Peter D. Rohde

REFERENCES

'Royal College of Psychiatrists (1977) The responsibility of the consultant in psychiatry within the NHS. Bulletin of the Royal College of Psychiatrists, September 1977, 4-7.

2Department of Health and Social Security (1980) Organisation and Management Problems of Mental Illness Hospitals (The Nodder Report). London: HMSO.

(1977) The Role of Psychologists in the Health Service (The Trethowan Report). London: HMSO.

(1978) Report of the Committee of Inquiry into Normansfield Hospital. Cmnd. 7357. London: HMSO.

\footnotetext{
Anumal Elections

Honorary Officers, Council and Court of Electors

Fellows and Members of the College are reminded of their rights in connection with the forthcoming elections for the offices of Dean, Registrar, Treasurer, Editor, Librarian and Sub-Deans. All Honorary Officers are eligible for re-election, except Dr Sheila Mann (a Sub-Dean), who has served five years.

The nominating meeting of Council will be held on 13 April 1984, and the last date for receiving nominations will therefore be 1 May 1984. Nominations may also be submitted for vacancies on the Court of Electors and for Elected Members of Council. The relevant extracts from Bye-Laws and Regulations may be found in the Bulletin (March 1983, 7, 58).
}

\section{Memorial to Professor Trevor Gibbens}

Members of the College will have been saddened to learn of the death of Professor Trevor Gibbens, Emeritus Professor of Forensic Psychiatry in the University of London. The Institute of Psychiatry is proposing to establish a research prize in his name in order to encourage, as he would have wished, young academics from all disciplines to learn research skills relevant to psychiatry and to criminology. Anyone who would like to contribute to this fund should send a cheque to the Institute of Psychiatry, De Crespigny Park, Denmark Hill, Camberwell, London SE5. Cheques should be made payable to 'The Institute of Psychiatry (Gibbens Fund)' and envelopes should be marked for the attention of Professor John Gunn. 